\title{
O IMAGINÁRIO DO CADÁVER EM DECOMPOSIÇÃO: DAS DANÇAS MACABRAS AO ROMAN-CHAROGNE
}

\author{
Juliana Schmitt \\ Faculdade das Américas \\ Faculdade Paulista de Artes \\ Centro Universitário Belas Artes de São Paulo \\ São Paulo, SP, BR.
}

\begin{abstract}
Resumo
A imagem do cadáver humano em seus processos de decomposição post-mortem se tornou parte das manifestações culturais e artísticas no Ocidente a partir do surgimento dos temas macabros na Baixa Idade Média, em especial nas "Danças Macabras", entre outros. Verdadeira obsessão medieval, o corpo em putrefação reapareceria como objeto estético na literatura de horror do Romantismo, que se convencionou denominar "gótica". Dentre essa produção, destaca-se o chamado "roman-charogne", gênero que abusava da referência macabra, explorando as características do cadáver decomposto de maneira sem antecedentes. $\mathrm{O}$ artigo busca levantar esses exemplares e problematizar a presença do morto putrefato neles, que responderia a demandas específicas de suas épocas.

Palavras-chave: Macabro; Danças Macabras; roman-charogne; Romantismo; História da morte.
\end{abstract}

\section{THE IMAGINARY OF THE DECAYING CORPSE: FROM THE DANCE OF DEATH TO THE ROMAN-CHAROGNE}

\begin{abstract}
The image of the human corpse throughout its post-mortem decomposition has become part of the cultural and artistic demonstrations in the West, beginning with the appearance of the macabre themes in the Late Middle Ages, especially the "Dance of Death". A true obsession in the medieval times, the putrid body would reappear as an aesthetic object in the horror literature, also known as "gothic". The so called roman-charogne, literary style that abuses of macabre references, outstands within this production, exploring aspects of the decaying corpse as never seen before. This article aims to point out these examples, problematizing the presence of the rotten dead body that would answer specific demands of those times.
\end{abstract}

Keywords: Macabre; Dance of Death; roman-charogne; Romanticism; History of death.

Ainda que seja o fato humano mais universal e inevitável, a morte, no decorrer do tempo e das civilizações, foi vista de diversas maneiras. É somente com a cristandade medieval, no entanto, que a figura do cadáver passa a fazer parte importante do imaginário relativo ao óbito. Presente na arte mortuária e em obras do gênero do Encontro dos três vivos com os três mor- tos e, principalmente, das "Danças Macabras", o corpo putrefato simbolizava a igualdade dos homens perante a morte, independente de classe, gênero ou idade. Era também a prova da superioridade da alma perante a carne - a primeira, salva pela redenção dos pecados, a segunda, condenada à dissolução repugnante. Séculos depois, os mortos em decomposição voltariam a povoar

\footnotetext{
* Juliana Schmitt é doutora em Letras pela Universidade de São Paulo e historiadora com especialização em História da Arte pela Universidade Estadual de Londrina. Professora do Departamento de Design na Faculdade das Américas, na Faculdade Paulista de Artes e no Centro Universitário Belas Artes de São Paulo, atua como pesquisadora nas áreas de História da morte e História do vestuário. Email: juschmittju@gmail.com.
} 
a literatura ocidental através da sensibilidade romântica do início dos oitocentos, que explorava seu aspecto impactante, notadamente em textos como Melmoth, the wanderer (1820), de Charles Maturin, Lâne mort ou la femme guillotinée (1829), de Jules Janin e Champavert (1833) de Pétrus Borel.

\section{Origens do imaginário macabro}

Datam da Baixa Idade Média os primeiros exemplares de obras, tanto literárias quanto iconográficas, que exploraram o tema do cadáver em decomposição. Historiadores das mentalidades que estudaram as fabulações a respeito da morte nos séculos medievais (como o pioneiro Johan Huizinga, Philippe Ariès, Michel Vovelle, entre outros) entendem que o período teria desenvolvido uma curiosidade obsessiva pelo corpo decomposto: "É como se o espírito do final da Idade Média não pudesse enxergar a morte sob outro aspecto além do da deterioração" (HUIZINGA, 2010, p. 221).

Não é à toa. Em uma época castigada por fomes e epidemias, era fácil um homem presenciar uma morte terrível e projetar, nela, seu próprio fim. Com um realismo mórbido, os artistas se esforçam em traduzir para suas obras o caráter horrível da Peste Negra, insistindo nos trespasses fulminantes e naquilo que o contágio tinha de mais odioso, inumano e repugnante.

Pode-se imaginar que as histórias sobre as pilhas de cadáveres putrefatos nas cidades e vilas tenham ficado de herança para as gerações seguintes. A epidemia não cessou plenamente e focos da doença reapareceriam esporadicamente em diversos lugares durante os três séculos seguintes, relembrando a sua rapidez e ferocidade.

O fascínio pela morte física era, então, particularmente observável nas representações dos processos post-mortem na iconografia e na literatura - o que se convencionou chamar, portanto, de "macabro": "o adjetivo que para nós adquiriu uma nuance de significado tão nítido e próprio, a ponto de, com ele podermos marcar toda a visão de morte do fim do período medieval" (HUIZINGA, 2010, p.231). Assim, agora citando Philippe Ariès, "costumam-se chamar 'macabras' as representações realistas do corpo humano durante a sua decomposição. O macabro medieval co- meça depois da morte e pára no esqueleto dessecado" (1989, p. 118), ou seja, é a morte úmida, o estágio de "transi”, como passou a ser denominada essa condição transitória da dissolução.

Fosse como cadáver repulsivo, corpo ressequido ou esqueleto, o morto era mostrado e descrito de uma maneira sem antecedentes. Insiste-se na exposição da podridão, em especial do abdômen - estufado ou aberto e abarrotado de vermes exaltados, ou vazio, com as peles penduradas. "Isso significa que se quer mostrar o que não se vê, o que se passa debaixo da terra e que é, na maioria das vezes, escondido dos vivos", ainda segundo Ariès. "O que a arte macabra mostrava era precisamente o que não se via, o que se passava debaixo da terra, o trabalho escondido da decomposição, e não o resultado de uma observação, mas produto da imaginação" (1989, p. 147).

Com insistência, a partir do século XII, o cadáver vai se tornando tema mais frequente, aparecendo nos Vers de la mort (1194-1197) do monge cisterciense Hélinant de Froidmont, e no De contemptus mundi (11941195), de Lotario de Conti, mais tarde papa Inocêncio III, para ficarmos em dois textos que tiveram certa repercussão à época. Ainda assim, eram autores conhecidos sobretudo no meio eclesiástico, com menor reverberação entre as gentes simples e, em geral, analfabetas. Foi somente com a aparição das representações iconográficas que o imaginário do corpo em decomposição efetivamente se popularizou.

$\mathrm{Na}$ arte funerária, por exemplo, é notável o aparecimento de esculturas portando a marca do que se consideraria macabro por volta de meados do século XIV. As efígies tumulares, até então, representavam o falecido sobre a sua tumba como jacente, em posição de dormir, de olhos fechados, mãos postas sobre o peito, vestido ou envolvido em mortalha, com expressão calma, plácida. "Les gisants sont sereins et sûrs de leur mort qui est leur vie éternelle", lembram Bertrand e Hélène Utzinger. No momento seguinte, porém, surgem imagens impressionantes, mesmo para a época:

l'art de la mort se transforme profondément; toute mort porte la marque de la désolation, de la pourriture, de la consternacion et, par-delà, 
d'une certaine inquiètude. A l'évidence, en moins d'une génération, la tempête remplace le calme, la torture artistique remplace la sérénité, le rictus remplace le sourire, lanatomie remplace le vêtement, le ver remplace le vair, le transi remplace le gisant, la pourriture remplace la vie éternelle. (UTZINGER, 1996, p. 45)

$\mathrm{Na}$ efígie da tumba (um cenotáfio, na verdade) de François de La Sarra (ca. 1363, o monumento foi erigido entre 1380-1400), na Capela de Saint-Antoine, em Vaud, na Suíça, sapos cobrem seu rosto e seus genitais, e serpentes atacam seus braços e pernas. O médico Guillaume de Harcigny, cuja sepultura, de 1393, encontrase no Museu de Laon, na França, foi representado com sinais cadavéricos evidentes: um corpo completamente nu, ressequido, com esqueleto já visível por baixo da pele. No caso de tumbas compostas (com dois andares) deste mesmo período, o andar de cima apresentava uma escultura tradicional de jacente enquanto que, no de baixo, o cadáver era mostrado em pleno processo de decomposição - como se quisessem, literalmente, mostrar o que acontece debaixo da terra. O exemplo mais conhecido é a do cardeal Jean Lagrange, falecido por volta do ano 1402, em Avignon, cuja parte de baixo de sua escultura tumular está no Musée du Petit Palais d'Avignon. Este tipo de construção foi feito ainda no monumento do arcebispo Richard Fleming, em 1430, na catedral de Lincoln, e na do arcebispo Henry Chichele, de 1443, na Catedral de Canterbury, ambas na Inglaterra. Incomuns até o século XIV, são contabilizadas cerca de 75 peças desse tipo no século XV, e 160 no XVI (ARIÈS, 2003, p. 150).

Mas a arte funerária não foi o principal suporte da imagética macabra. Na passagem para os quatrocentos, vêm à tona as ilustrações da lenda d'O encontro dos três mortos com os três vivos. A cena em que três cadáveres encontram-se e conversam com três homens tornou-se um gênero literário e iconográfico popularíssimo no fim da Idade Média. No Encontro os vivos não são convidados a partir imediatamente. Trata-se de um aviso para que aproveitem o tempo que lhes resta para praticarem o bem, arrependerem-se e garantirem, assim, uma boa morte. De origem obscura, provavelmente francesa, é um dos temas responsáveis pela difusão do macabro no Ocidente. Isto se deve à representação plástica dos mortos: via de regra, apresentam os três estágios físicos post-mortem - e aí reside sua originalidade.

Distingue-se, assim, graficamente, os diferentes momentos da desintegração dos restos mortais: o primeiro cadáver está ainda bem conservado, possui certas características físicas e sociais (como trajes e objetos pessoais) da pessoa que foi, apresentando poucos sinais de deterioração. $\mathrm{O}$ segundo, quase nu, às vezes coberto por mortalha, tem o corpo bastante danificado, o ventre aberto ou estufado. O último, em geral, é já um esqueleto, ou praticamente um, com restos de pele ressecada colada aos ossos. Como em um espelho, os mortos refletem os vivos, lhes oferecendo a visão de sua aparência futura.

O primeiro texto do Encontro do qual se tem registro é anônimo e data da década de 1280; no entanto, não há cópia preservada desse original. $\mathrm{O}$ mais antigo dos manuscritos preservados data de 1295 e é atribuído ao menestrel Baudoin de Condé (1244-1280), da corte da condessa Marguerite de Flandres. Os versos são acompanhados da primeira gravura registrada do gênero, representando a cena. $\mathrm{O}$ documento foi depositado na Biblioteca de Arsenal (Ms. 3142). No século seguinte, foi traduzido em diversas versões em línguas vulgares, no alemão e no castelhano, entre outras, e as páginas eram, normalmente, bastante ilustradas. Acredita-se que o relato tenha entrado para a tradição oral, sendo contado como exempla pelas ordens mendicantes e se espalhado. Seus detalhes eram alterados de acordo com o local em que apareciam, como o estado de decomposição dos mortos ou o grupo social e a faixa etária dos vivos - na França, por exemplo, a lenda conta a história de três jovens nobres cavaleiros que saem à caça, com seus cães, quando são surpreendidos. Mas sua essência pedagógica sempre se manteve.

A primeira pintura mural com o tema foi, provavelmente, a da Igreja de Sainte-Ségolène de Metz, do fim do século XIII (destruída entre 1895-1910), momento em que o motivo se populariza, migrando para toda a cristandade. Os exemplares imagéticos mais conhecidos e estudados são o afresco do cemitério do Camposanto de Pisa, de meados do século XIV, e o do convento beneditino de Subiaco, do século XV, ambos na Itália. O Encontro foi também amplamente utilizado 
para ilustrar textos genéricos sobre a morte e em objetos pessoais, como em livros de horas.

Contemporâneas às reproduções dos três mortos com os três vivos, as "Danças Macabras" talvez sejam a mais conhecida manifestação do macabro medieval. É assim denominada toda obra textual ou iconográfica - ou ambas -, que apresenta um desfile de personagens no qual parte deles está morta, parte, viva. Pode se configurar como uma fila ou uma procissão, uma ciranda ou uma cena dançada. É presidida por um cadáver, que pode ser múltiplo (a mesma personagem que reaparece várias vezes) ou um grupo (vários cadáveres, os enviados da Morte). Até o século XVI, eram geralmente apresentados com a aparência de transis. Após, como esqueletos. Em movimento, um morto segura, ou puxa, um por um, os vivos. Estes representam a sociedade e aparecem sempre em hierarquia descendente. Cada qual simboliza uma categoria social, um estágio da vida, um estado emocional, um gênero. Sempre presentes nessas obras, estão figuras importantes como o papa, o imperador, o rei, o cardeal, o burguês. Mas outros membros fundamentais da sociabilidade medieval são também contemplados, como o artesão, o camponês, o frade mendicante, a criança. Seu contato com um morto significa que está sendo levado a óbito e a variedade de personagens enfatiza o caráter universal da morte.

É comum, também, a participação de cadáveres que tocam instrumentos musicais - destacando o elemento rítmico do gênero. Nesse sentido, a legitimidade do termo "dança" se daria muito mais pela presença dos transis músicos entre os personagens representados (às vezes abrindo ou fechando o desfile) e, especialmente, pela postura dos mortos que, excitados pela sua função, estão sempre em movimento - ao contrário dos vivos, que congelam. Essa inversão é, em si mesma, uma sátira: os mortos, animados, parecem muito mais vivos que seus pares.

As expressões "Dança da Morte", "Dança dos Mortos" ou "Danças Macabras" são empregadas indistintamente para denominar o tema, apesar de portarem uma pequena diferença conceitual. Essa seria no sentido de estabelecer a identidade precisa do(s) personagem(ns) morto(s): se se trata de um grupo de mortos que representa a morte ou personifica o evento da morte, ou se é "a" própria Morte, individualizada. Neste caso, a Morte chama à sua dança fatal os vivos; no anterior, o morto que aparece diante do vivo seria, dependendo da interpretação e, às vezes, do que sugere o texto, um personagem aleatório e anônimo, ou uma espécie do duplo do vivo, seu espelho, que reflete o futuro inevitável.

O exemplar mais relevante das Danças foi um afresco pintado no cemitério de Saints Innocents, em Paris, em 1424. É considerada a primeira obra registrada do gênero, reunindo texto e imagem. Sua grandiosidade causou grande impacto à época: na parte interna de um dos muros que cercava o terreno, na pintura de 20 metros de extensão, cerca de 30 personagens eram chamados à dança da morte. Cada um era acompanhado por seu par-cadáver, e, abaixo, pelos versos do poema. A obra localizava-se abaixo de um dos carneiros do cemitério - as galerias construídas sobre os muros para receberem os ossos que não estivessem completamente limpos mas que deveriam ser retirados das fossas comunais para abrir espaço para novos corpos. A visão das pilhas de ossos ainda cobertos de pele ou carne ressequida combinada à visão do afresco provavelmente intensificava o efeito da obra.

Supõe-se que naqueles anos anteriores à confecção da pintura, suas valas comunais estivessem abarrotadas, pois concentravam as vítimas da peste de 1421, da grande fome de 1417 e da guerra contra a Inglaterra, que perdurava. Estima-se cerca de 100 mil mortos enterrados lá em 1418 (UTZINGER, 1996, p.83). Inspiração não faltava, portanto, ao artista anônimo que empreende essa grande obra a partir de novembro de 1424 (terminada cinco meses depois).

Apesar de posteriormente destruída (parte em 1529, totalmente em 1669), ${ }^{1}$ foi demasiadamente documentada e comentada, inspirando a confecção de outros afrescos por toda Europa cristã. Dos que resistiram aos séculos, podendo ser visitados ainda hoje, considera-se o exemplar da igreja abacial de La Chaise-Dieu o que mais se aproxima da aparência da original parisiense. Trata-se de uma obra interminada e mesmo assim monumental: possui 26 metros de extensão por 1,50 de altura e é dividida em três grandes painéis, que ocupam uma parede interna da nave. Seus 23 personagens, de- 
vidamente acompanhados de seus parceiros defuntos, estão separados em grupos correspondentes à sua posição social. Não há consenso sobre a data precisa de sua produção, mas a análise indumentária considera que tenha sido feita até, no máximo, a década de 1480.

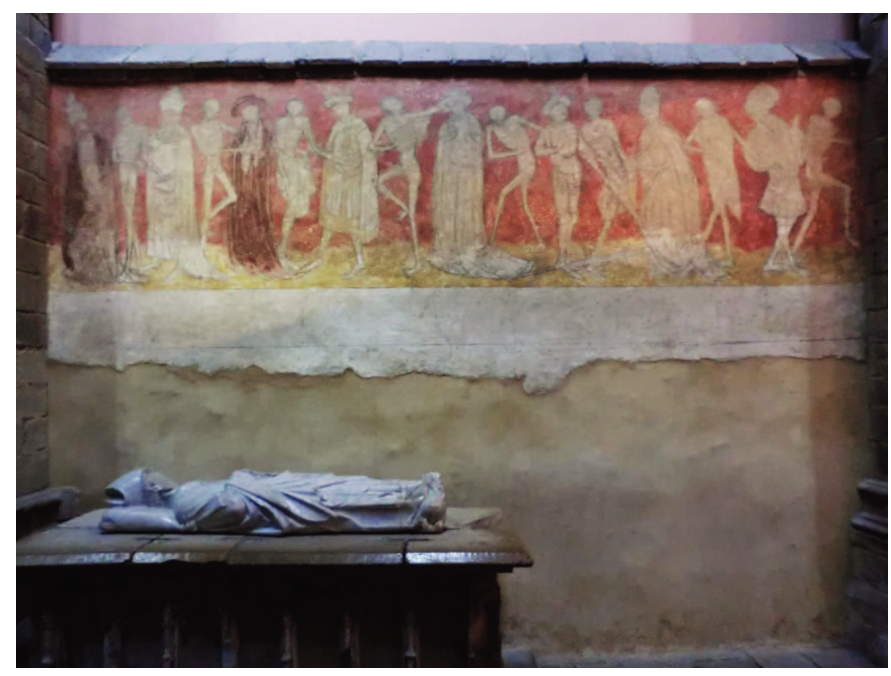

O primeiro painel, com os poderosos da sociedade (Papa, Imperador, Cardeal, Rei, Abade, Condestável, Bispo, Cavaleiro), acompanhados de seus respectivos transis. Fonte: acervo pessoal da autora.

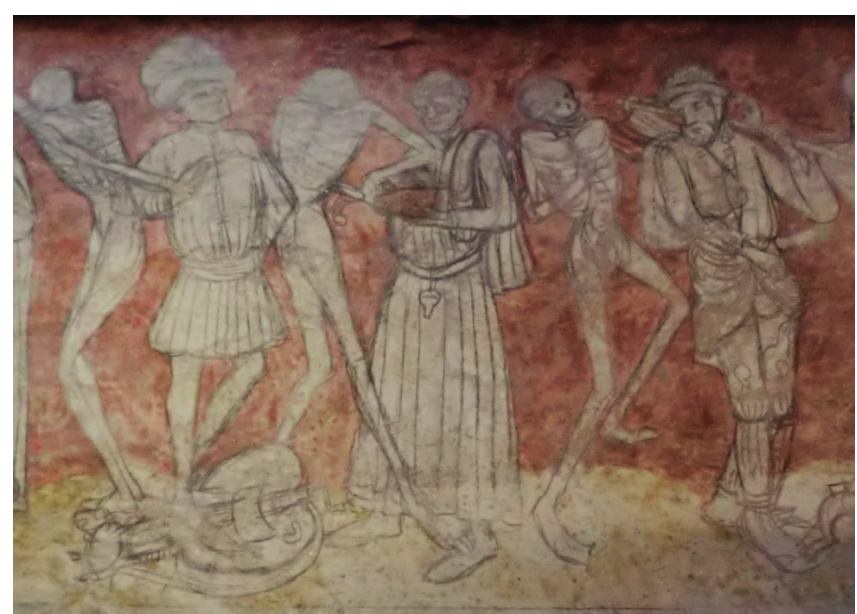

Detalhe do terceiro painel, com os mais humildes da sociedade. Os três transis levam consigo o menestrel, um religioso e o camponês. Fonte: acervo pessoal da autora.

A pequena igreja românica de Meslay-le-Grenet, no departamento francês de Eure-et- Loir, construída no século XII, também foi suporte para pinturas murais no final do século XV. As paredes, praticamente sem janelas, do prédio simples de teto baixo, receberam diver- sos temas em voga no período: um "Encontro dos três mortos com os três vivos"; a "Lenda do Rei morto", as "Mulheres tagarelas na missa" e uma Dança Macabra, além de uma Paixão de Cristo atrás do altar. A dança de Meslay-le-Grenet também parece ter sido feita aos moldes do afresco parisiense; pela proximidade entre as duas cidades, é de se supor que reproduções chegaram aí rapidamente. Apesar disso, ela possui um elenco menor devido às dimensões diminutas do edifício - são 20 pares transi-vivo, no total. Ao contrário da Dança de La Chaise-Dieu, possui as estrofes em oito versos referentes à fala de cada personagem, ainda hoje bem visíveis - todas as pinturas foram descobertas em 1864 e, possivelmente, restauradas.

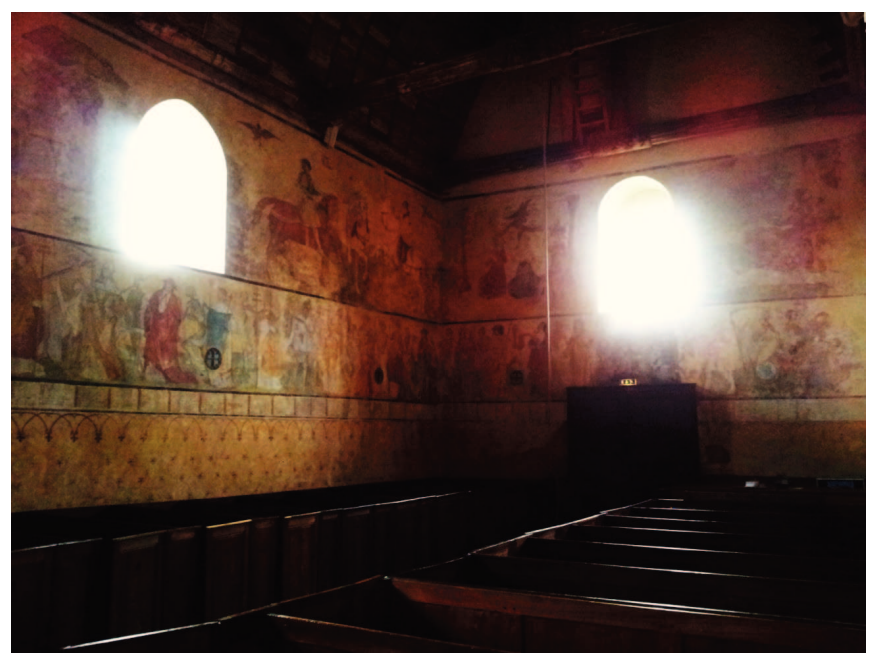

O lado sul da nave principal, com a Dança macabra e os outros temas. Fonte: acervo pessoal da autora.

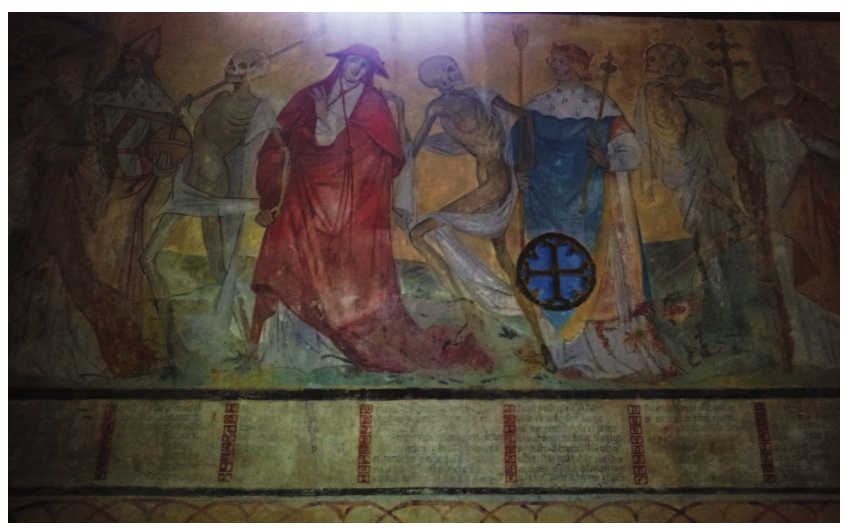

Detalhe da Dança de Meslay-le-Grenet: transis levando o Imperador, o Cardeal, o Rei e o Abade. Fonte: acervo pessoal da autora. 
A Dança de Saints-Innocents foi também bastante reproduzida em versões impressas e em gravuras que viajaram a Europa. A Biblioteca Nacional da França possui pelo menos 13 manuscritos de supostas cópias dos mesmos versos escritos na parede do cemitério parisiense. O mais antigo (Ms. fr. 25550 fol. 235) é anônimo e intitulado "Les vers de la danse macabre de Paris, tels qu'ils sont présentés au cimentière des Innocents". Esses textos passaram a ser distribuídos na década de 1480. Entre essas publicações, a mais famosa e provavelmente a maior responsável por sua difusão é um conjunto de xilogravuras acompanhadas de versos, publicado pelo editor parisiense Guyot Marchand, em 1485. Acredita-se que seja um registro bastante fiel tanto do texto quanto da pintura, reproduzindo os mesmos personagens na mesma configuração. Apenas um exemplar desta edição foi conservado e encontra-se na Biblioteca Municipal de Grenoble. A "Dança de Marchand", como passou a ser chamada, teve diversas edições - a primeira já no ano seguinte, aumentada em dez novos personagens, e acrescida da história do Encontro entre os três mortos e os três vivos, de uma Dança macabra das mulheres (de autoria de Martial d'Auvergne), e dos versos do Vado mori. Uma verdadeira "coletânea macabra" de grande sucesso comercial, o que comprova a força do tema à época. Tamanha repercussão gerou inúmeras cópias do modelo de Marchand, como a Danse Macabre a Paris, por Pierre Le Rouge, a mando do editor Antoine Vérard, que as publica em 1491, e Simulachres \& histoires facées de la Mort, de Hans Holbein, o jovem, de 1538.

Com a divulgação por Marchand dos supostos versos e personagens da Dança original de Saints-Innocents, o gênero ganha um modelo, um formato razoavelmente padronizado que foi replicado em diferentes suportes (manuscritos, afrescos, gravuras, esculturas) e difundido por toda Europa Ocidental no final do século XV e no decorrer do século XVI. Levantamentos ${ }^{2}$ apontam que a Alemanha é o território que possui o maior número de exemplares documentados (pelo menos 36). A França vem na sequência, com cerca de 28. Onze danças são italianas, doze provêm da Suíça, 5 da Áustria. Na Inglaterra são também 5, enquanto que na Grã-Bretanha, por volta de 14. Quatro danças, apenas de textos, são espanholas. A Polônia, a Dinamarca, a Estônia e a Finlândia participam desta lista contando com 1 ou 2 danças, cada. Destes exemplares, alguns tornaram-se popularíssimos, devido ao grande impacto que causaram à época, ajudando a disseminar a cultura do macabro. Infelizmente, grande parte desse inventário já não existe mais ou encontra-se bastante degradada.

Enquanto o Encontro e as Danças (e, por extensão, outros temas recorrentes como os Ars Moriendi, os Triunfos da Morte e os Livros de horas, que vez ou outra exibiam também cadáveres) ajudavam a tornar o macabro visível e imagético, havia ainda uma produção poética que falava dessa mesma maneira ostensiva sobre a decomposição do corpo. Os versos de Pierre de Nesson (1383 - ca. 1442) foram particularmente significativos nessa leva de obras que exaltam a carniça e a podredume em um poema que, originalmente, não tinha título, mas cujas versões posteriores trataram de denominar Neuf leçons de Job e, mais tarde, Vigiles des morts (o manuscrito mais antigo encontra-se na Biblioteca Nacional da França [Ms. fr. 578 fol. 122-130]). O autor enumera nove lições retiradas, por sua livre interpretação, do Livro de Jó e, em seguida, reflete sobre elas, em versos notadamente macabros. Para ele, o homem está fadado a apodrecer desde que nasce ("Tu nais et puis tu te norris; / Tu vis puis muers et puis porris; / Et, apres ce, tu n'es mes rien.") e, ao contrário da natureza que oferece flores perfumadas e frutos que alimentam, o homem não é mais que secreções, fedor, corrupção. Em Nesson, lê-se que a morte não é alívio; pelo contrário, é dolorosa, pois após o trespasse, só resta ao corpo decompor-se e, por isso, não há para ele lugar nesse mundo - dejeto repugnante, infecta o ar, a água, a terra.

É pouco o que se conhece a respeito do poeta, no entanto, "ce que nous pouvons affirmer, c'est que Leçons de Job ont eu un grand succès, qu'elles correspondaient bien au sentiment de cette époque funèbre. Car nous en connaissons de nombreux manuscrits" (CHAMPION, 1923, p. 213).

São versos eloquentes da sensibilidade macabra também aqueles atribuídos ao rei René d'Anjou (14091480), escritos em uma tela de sua autoria que, até a Revolução Francesa, ficava no convento dos celestinos, em Avignon (e que, depois, desapareceu). O quadro, 
sem data precisa, mostrava um cadáver feminino em pé, bem penteado, envolto em mortalha, que os vermes atacavam ferozmente. Os primeiros versos falam da transformação da bela dama, fresca e tenra, que vestia seda e habitava um palácio, em um corpo nu que vai se tornar cinzas dentro de um caixão em uma fossa cheia de sevandijas.

Também o manuscrito original do poema inglês Disputacioun Betwyx the Body and Wormes (ca. 14351440) conta com impressionantes ilustrações que complementam o teor macabro do texto. Herdeiro do gênero do Debate entre a alma e o corpo, o Disputacioun traz uma diferença essencial com sua ascendência: o diálogo que se estabelece não é entre o corpo e a alma mas entre o corpo morto e os vermes que o devoram na sepultura. O documento, anônimo, está depositado no British Museum (Ms. Add. 37049), em uma coletânea de textos do começo do século XV, recolhidos em um monastério cartuxo do norte da Inglaterra. Em sua primeira página, uma ilustração em cores do que parece ser um túmulo composto, de dois andares, ou os dois estágios da morte física: no de cima, uma efígie de jacente, uma figura feminina, vestida à moda da época, semblante sereno e mãos postas sobre o peito. No de baixo, seu cadáver retorcido, embrulhado em mortalha, de pele ressequida e caveira aparente, sem cabelos, infestado de vermes, baratas e animais infames de toda sorte.

François Villon, com a habilidade que tem um grande poeta, não precisou de mais do que uma estrofe para descrever as perturbações físicas e a agonia do fim da vida:

La mort le fait fremir, pallir,

Le nez courber, les vaines tendre,

Le col enfler, la chair mollir,

Joinctes et nerfs croistre et estendre. ${ }^{3}$

Suas meditações pungentes sobre a morte, seu assunto preferido, fizeram com que o Grand Testament, de 1461, fosse uma obra muito lida em sua época e nos séculos seguintes. Francês nascido em Paris, cidade na qual eventualmente residia, Villon, como muitos de seus contemporâneos, conhecia e frequentava o cemitério de Saints-Innocents. Lá ficava ainda mais latente sua atração pela morte física, que via exposta sem constrangimento nos ossuários e carneiros, amontoados de despojos ali depositados indistintamente - pobres ou ricos, senhores ou servos.

Quand je considère ces têtes
Entassés en ces charniers
(...)
Et icelles qui s'inclinaient
Unes contre autres en leurs vies;
Desquelles les unes régnaient
Des autres craintes et servies:
Là les vois toutes assouvies,
Ensemble en un tas pêle-mèle:
Seigneureries leur sont ravies.
Clerc ni maître ne s'y appelle.

Por serem escritos em língua vulgar e não no latim, estima-se que estes textos tiveram a atenção também de um público menos letrado e culto. Seu real alcance, assim como seu verdadeiro lugar na difusão do macabro, é difícil de mensurar. A esse respeito, sabe-se do papel fundamental das ordens mendicantes em popularizar a imaginação macabra. Tanto a iconografia (em especial as gravuras, por sua portabilidade), quanto a literatura, foram instrumentos bastante explorados pelos frades em suas peregrinações. Seus sermões insistiam na pobreza, no arrependimento, na caridade, nas obras, como garantias necessárias de uma boa morte e da salvação da alma. O macabro funcionava como um memento mori expressivo, corroborando com esse discurso através do medo da corrupção da carne e do horror post-mortem.

\section{Os cadáveres do roman-charogne}

O imaginário do cadáver em decomposição se popularizou após a Baixa Idade Média. A tarefa de traçar seus percursos no decorrer dos séculos modernos é difícil: reapropriado por obras de natureza outra, que não tinham por objetivo os ensinamentos cristãos que garantiam uma boa morte e exploravam seu aspecto horrível e repugnante, o macabro medieval se fundia a gêneros literários e iconográficos como o do terror ou do grotesco, por exemplo. Esvaziado do seu poder pedagógico, o cadáver servirá, nessa literatura, como um potencializador das cenas de horror. 
O final do século XVIII testemunha uma redescoberta dos temas da cultura medieval, tendo por catalisadora a já conhecida obsessão dos românticos pelo período: "Le moyen âge est sans doute l'époque historique vers laquelle, en imagination, le romantisme s'est le plus intensément projeté" (VAILLANT, 2011, p. 477). Essa inclinação está presente mesmo no seu léxico: é bastante conhecida a definição de Mme de Staël, de 1813, segundo a qual "o termo 'romântico' foi introduzido recentemente na Alemanha para designar a poesia que teve origem nas canções dos trovadores, a que nasce da cavalaria e do Cristianismo" (in GOMES, 1992, p. 87).

A voga teria sido estimulada por diversos fatores. O grande interesse historiográfico de uma geração de pesquisadores que trouxe à tona a cultura medieval sem o preconceito iluminista, como John Ruskin, Champollion-Figeac, Hyacinthe Langlois ou Jules Michelet, que resultou em textos impregnados de emoção saudosista. Também a redescoberta de autores da época, como François Villon, e a republicação de romances de cavalaria ou de peças literárias como as Reliques of Ancient English Poesy, do Bispo Percy, em 1765, que recuperava baladas populares - ou, ainda, a invenção dessa mesma literatura (como no caso emblemático dos Cantos de Ossian), foram particularmente importantes a esse processo. O fascínio pelo estilo gótico na arquitetura (cujas catedrais inspiraram Caspar David Friedrich, John Constable e Pérez Villaamil, e eram elogiadas por Goethe), e sua retomada no neo-gótico (do qual as restaurações executadas por Viollet-le-Duc pela França ou mesmo a concretização dos delírios monumentais de Horace Walpole, na Inglaterra, são apenas dois exemplos) são outras facetas da mesma moda.

A Idade Média cumpriria, para esse início de Romantismo, o papel de mito fundador, uma pré-história da sociedade moderna, em contraposição à Antiguidade, modelo para o Neoclassicismo. A pastoral medievalista via nos tempos de outrora a cura para uma certa melancolia que invadia as mentalidades coletivas no limiar do século XVIII. "Le romantisme", lembra Edgar Morin, "est tout d'abord crise d'inadaptation à l'embourgeoisement" (1997, p. 300). Idealizado, o período anterior ao surgimento da sociedade industrial e do capita- lismo era valorizado como o da vida em comunidade, de povos primitivos que se relacionavam harmônica e intimamente com a natureza e com a religião.

"Cette création d'un monde arbitraire, où le moi, heurté par la dure realité, puisse sépanouir, c'est le mouvement premier de lâme romantique", confirma Albert Béguin (1986, p. 50). E a dura realidade da qual buscavam escapar os românticos era a desse tempo regido pela máquina, revelando o temor da mecanização do próprio homem, do qual a história da Olympia de Hoffmann é representativa, e o Frankenstein de Shelley, um sintoma. "A Idade Média é glorificada; épocas pós-medievais são escolhidas só para descrever, com nostalgia, a derrota e o desparecimento de tradições veneráveis" (CARPEAUX in GUINSBURG, 1993, p. 163). Portanto, a retomada da cultura medieval explicaria, em parte, $o$ reaparecimento do macabro, embora não tenha sido a única responsável.

A triunfante moral burguesa pós-revolucionária refletia esse estado de inércia amorfa, mais preocupada com o consumo e com sua imagem social do que com os rumos da civilização. O período da consolidação de seu estilo de vida, contemporâneo ao desenvolvimento do Romantismo, na passagem do século XVIII para o XIX, não por acaso, recebeu o epíteto de "a gélida era da burguesia" por Eric Hobsbawm:

\footnotetext{
Um protestantismo beato, rígido, farisaico, sem intelectualismo, obcecado com a moralidade puritana a ponto de tornar a hipocrisia sua companheira automática, dominou essa desolada época.(...) Seus homens personificavam o dinheiro, que provava seu direito de dominar o mundo; suas mulheres, que o dinheiro dos maridos privava até da satisfação de realmente executar o trabalho doméstico, personificavam a virtude da classe: ignorantes, sem instrução, pouco práticas, teoricamente assexuadas, sem patrimônio e protegidas. (2006, p. 263-4)
}

A despeito desse "protestantismo beato", os tempos eram nitidamente anticlericais, em que cada vez mais se afrouxavam os laços ideológicos que ligavam o homem à religião, em especial nas cidades: "Embora em termos puramente quantitativos e religião continuasse muito forte, ela não era mais dominante mas recessiva.(...) 
A tendência geral do período desde 1789 até 1848 foi, portanto, de uma enfática secularização" (HOBSBAWM, 2006, p.306-9). O discurso racionalista impregnava as discussões filosóficas, influenciando também uma minoria de livres-pensadores que buscava se desvencilhar da Igreja. "A crítica da religião empreendida pela filosofia do século XVIII enfraqueceu o cristianismo como fundamento da sociedade", relembra ainda Octavio Paz. (1984, p. 75).

Ainda que a grande maioria da população, em especial as massas camponesas e proletárias, continuasse crente, essa mudança de fundo ocorria de forma tão sutil e gradual que só era possível observá-la nas nuances do comportamento humano e em algumas de suas manifestações visíveis - como na laicização dos testamentos, documentos até então impregnados de discurso piedoso e que se tornaram meros registros de transferência de patrimônio. ${ }^{5}$ Diante desse dado, seria possível afirmar que, ao mesmo tempo em que as religiões continuavam a existir, intimamente os homens pareciam duvidar cada vez mais de seus pressupostos, sendo um deles, a conviç̧ão da imortalidade da alma, um dos bastiões da fé cristã. Era "o fim de um monopólio ideológico”, diria Michel Vovelle (1983, p. 532). O óbito passava a ser considerado uma ruptura brusca, o desfecho da única realidade da qual se tinha certeza.

Mesmo que permanecesse corrente o discurso religioso, às vezes em suas formas mais histéricas, vide a emergência e o fortalecimento das correntes evangélicas em meados do século XIX, era inegável o processo de materialização do óbito. Dessacralizada, tornada um fim absoluto, etapa incontornável da natureza, a morte se secularizava. Assim concebida, a vida se revelava uma existência vazia, que terminava nela mesma. Sem mistérios, sem segredos. A confiança de que, após a morte, se seguiria um renascimento, em outro plano, sob outra forma, espiritual ou seja qual fosse, fora abalada. Condenado a ser um corpo que apodrece, o homem amendrontava-se.

O resultado imediato dessa nova percepção foi, segundo Philippe Ariès, a origem do medo da morte que "manifestou-se pela repugnância, primeiro em representar e, depois, em imaginar o morto e seu cadáver" (2003, p. 158). A assepsia burguesa não aceitava o con- tato com a decomposição humana e passava a escondê -la, evitá-la. A morte, como um todo, vai, aos poucos, sendo tratada como um assunto tabu, que não podia ser mencionada e muito menos vista, e os mortos, considerados objeto de horror.

Nada mais provável, portanto, que a imaginação romântica, em sua vertente crítica da pudicícia burguesa, tomasse para si os temas que agrediam a sensibilidade da época e desafiavam a lógica racionalista. $\mathrm{O}$ redespertar do macabro foi um deles.

Théophile Gautier comentava, em seu prefácio à Mademoiselle de Maupin, a "recente" (o texto é de 1835) epidemia medieval que atacara Paris e os arredores, aparentemente sem grande importância - "certainement plus innocent que les jeux innocents, et qui ne faisait mal à personne." Mas o público "se prit d'un belle passion pour ce pauvre moyen âge" que invadia tudo: "drames, mélodrames, romances, nouvelles, poésies, vaudevilles." E revela um dos gostos mais emblemáticos à cultura do macabro da época, o "roman-charogne":

A côté du roman moyen âge verdissait le romancharogne, genre de roman très agreable (...) Les feuilletonistes sont bien vite arrivés à lodeur comme des corbeuax à la curée, et ils ont dépecé du bec de leurs plumes et méchamment mis à mort ce pauvre genre de roman qui ne demandait qu’a prospérer et a se putréfier paisiblement sur les rayons graisseux des cabinets de lecture. Littérature de morgue ou de bagne, cauchemar de bourreau, hallucination de boucher ivre et d'argousin qui a la fièvre chaude! Ils donnaient bénignement à entendre que les auteurs étaient des assassins et des vampires, qu'ils avaient contracté la vicieuse habitude de tuer leur père et leur mère, qu'ils buvaient du sang dans des crânes, qu'ils se servaient de tibias pour fourchette et coupaient leur pain avec une guillotine. Et pourtant ils savaient mieux que personne que les auteurs des ces charmantes tueries étaient de barve fils de famille, très debonnaires et de bonne société (...) Mais, quoi qu'ils dissent ou qu'ils fissent, le siècle était à la charogne, et le charnier lui plaisait mieux que le boudoir (...). (GAUTIER, 1876, p. 13-15, grifo nosso)

O "roman-charogne", de que fala Gautier, que se confunde com o "romance gótico" ou "negro", tinha como principais características a ambientação em 
construções medievais e uma narrativa que incluía elementos fantasiosos e mistério, componentes que confrontavam a lógica racionalista. Remeter-se a um passado remoto não gerava apenas o cenário desejado: os prédios góticos foram resignificados pelo Romantismo. As majestosas catedrais, com seus vitrais de reflexos oníricos e altíssimas torres tornavam-se enigmáticas; o castelo-fortaleza protegia e escondia segredos de outras gerações; o monastério, verdadeiro labirinto de quartos e capelas que ocultavam confissões e assassinatos: o terror e o crime encontravam aí seus cenários ideais.

Precursores, autores ingleses como Horace Walpole (The castle of Otranto, de 1765), Ann Radcliffe (The misteries of Udolpho, em 1794 e The Italian, de 1797), Mathew Gregory Lewis (The monk, de 1795), Mary Shelley (Frankestein, 1817) e Charles Maturin (Melmoth, 1820) inauguraram o gênero que desafiava os valores burgueses, e que reverberaria durante todo o século XIX. O crepúsculo das Luzes seria marcado pela "febre gótica", como comenta Eliane Robert Moraes:

A popularidade do gênero pode ser confirmada não só pelo grande número de publicações originais ou traduções colocados à disposição do leitor, mas também aferido pelas inúmeras reedições dessas obras. "O Castelo de Otranto", do medievalista Horace Walpole, que dá ao roman noir sua certidão de nascimento é um exemplo disso: de sua publicação original em 1765 até o final do século ele terá sucessivas edições. (1994, p. 74)

E foi nas ruínas artificiais de um passado medieval inventado que esse romantismo de evasão buscou falar de sua própria época: ficcionalizando as cenas brutais do Terror revolucionário e suas espetaculares execuções públicas, confrontando o leitor com seus medos mais íntimos. A inadequação da sensibilidade romântica ao mundo capitalista, que exaltava a moral, a contenção e a parcimônia, encontrou abrigo dentro dos prédios-fortaleza, de muralhas altas, cujas paredes grossas escondiam centenários corredores tortuosos e quartos ainda mais isolados. Os castelos que atraíam a imaginação romântica eram também circundados pela natureza mais selvagem que se poderia conceber. As sombras e a penumbra dessas paisagens forjadas forneciam a atmosfera de mistério ideal às narrativas.

"A emergência do romance gótico está associada a um sentimento que se apodera da Europa na época: o 'mal de vivre"' (MORAES, 1989, p. 76), (in)disposição do espírito que parece ter acometido toda uma geração na passagem do século XVIII para o XIX e que se expressava no "efeito Werther". Sabe-se da suposta onda de suicídios que teria acompanhado o lançamento do romance seminal de Goethe, em 1774, uma verdadeira epidemia que, juntamente à tuberculose (o tipo de morte por doença mais próxima ao suicídio, de acordo com as sensibilidades oitocentistas - daí seu nome em francês, “consomption"), substituía as verdadeiras hecatombes demográficas. Dado importante: enquanto o macabro medieval teria sido forjado na ressaca da Peste Negra que assolou a Europa, expondo as entranhas dos cadáveres obscenamente e a qualquer instante, a estética macabra era agora retomada como consequência (e, no limite, como antídoto) do estado generalizado de neurastenia. E isso em uma época em que a ciência aprendia a lutar de maneira mais eficaz contra as enfermidades, através da medicina ou dos avanços na cultura do cuidado de si (que poderíamos chamar anacronicamente de "higiene"), em que não apenas se morria menos por moléstias tratáveis, como também se vivia mais (a expectativa de vida teria aumentando em dez anos durante o século [VOVELLE, 1983, p. 510]). Em suma, o "mal" realmente preocupante era aquele que acometia a alma.

Além do Werther, o público europeu descobria naqueles anos a literatura gótica inglesa e rapidamente familiariza-se com os nomes de Horace Walpole, Ann Radcliffe, Matthew Gregory Lewis e Robert Maturin. Traduzidos e avidamente lidos, sem demora, influenciaram uma produção francesa cujo auge foram obras como Lâne mort ou la femme guillotinée (1829), de Jules Janin, e Champavert (de 1833) de Pétrus Borel. Além do "roman-charogne", o Romantismo francês gerou também a chamada "poèsie des cimetières", ${ }^{6}$ da qual poderia se citar, no mínimo, a Comédie de la mort, de Gautier, de 1838, e a Epopée du ver, de Victor Hugo, publicada em 1877, na Légende des siècles.

Esses textos ofereciam ao leitor vitoriano um verdadeiro catálogo macabro. Emblemáticas da vertente 
"frenética" do romantismo, segundo denominação de Charles Nodier, as narrativas eram recheadas de situações tétricas. $\mathrm{O}$ autor usa o termo em diversas ocasiões para caracterizar essas obras que, filiadas à tradição gótica, exacerbavam na violência e no horror, que agradavam o gosto de sua época.

O frenético encontrou no próprio Nodier seu propagador, seja em Smarra ou les démons de la nuit, de 1821, ou na coletânea de contos Infernalia, de 1822. O cadáver (ou, ainda, os cadáveres: na economia do roman-charogne, quanto mais, melhor) se tornava elemento essencial para acentuar o caráter aterrorizante de dado acontecimento e o romantismo frenético não via limites para a exposição dos corpos decompostos. Sem receio da repetição de certos temas, essa literatura recompensava um público ávido em sentir as delícias da violência e da morte fictícia.

Prazeres que se encontravam, por exemplo, em The monk, cujo enredo vale a pena resumir. Na trama de 1796, criada por Charles Lewis, não faltam ingredientes como estupro, incesto, assassinato, bruxaria e tortura. A pobre Agnes, sua maior vítima, prometida ao claustro pela mãe em seu nascimento, é encerrada grávida em um convento liderado por uma inescrupulosa abadesa. Para esconder o fruto de seu pecado, a jovem é aprisionada nas catacumbas, em um minúsculo calabouço úmido e escuro, rodeada de freiras mortas, que jaziam ao seu redor ("[...] surrounded by the loathsome and mouldering bodies of my companions"), e exalavam odores fétidos ("I was opprest by a noisome suffocating smell [...]"), algumas recém-deixadas nas tumbas ("What was my disgust, my consternation! In spite of its putridity, and the worms which preyed upon it, I perceived a corrupted human head, and recognised the features of a Nun who died some months before!"), além de "skulls, shoulder-blades, thigh-bones and other leavings of mortality were scattered upon the dewy ground." De noite, deitada em seu mísero leito de palha, sentia toda sorte de répteis infames caminharem sobre seu corpo - como que adiantando as sensações de seu cadáver sendo devorado, o que a apavorava ainda mais.

Os dias passavam e, com o sofrimento e a fome aguda que sentia, seu corpo adiantou o trabalho de parto, que ela teve que realizar sozinha. Sem condições de alimentar ou limpar seu bebê e com o ar gelado e infecto de sua masmorra, o pequeno morre em seus braços, apenas algumas horas depois de ter vindo ao mundo.

Uma freira se compadece da situação e se oferece para levar o pequeno cadáver para fora e enterrá-lo. Mas Agnes não concebe se separar do corpo, sua única companhia e conforto. Em pouco tempo, ele começa a apodrecer: "It soon became a mass of putridity, and to every eye was a loathsome and disgusting object."--menos aos seus olhos de mãe, que não permitiam vê-lo com aversão: "In vain did human feelings bid me recoil from this emblem of mortality with repugnance: I withstood, and vanquished that repugnance." Agnes passava o tempo amando e acarinhando o diminuto e asqueroso despojo, até o dia em que foi resgatada, encontrada assim, conversando com o mortinho, embalando-o em seu colo e beijando o pacotinho frio de seu corpo.

O encadeamento de horrores se repete em outra obra emblemática do frenético Lâne mort (1829), que também merece menção. Jules Janin, no prefácio, a chama de seu "castelo gótico", prenunciando a letra noir da narrativa. Apesar do começo idílico, assim que o narrador chega em Paris, a história descamba para uma mordaz crítica social, em uma série de acontecimentos que denunciam o paradoxo moral que permeia todo ato de sociabilidade urbana, que incentiva e ao mesmo tempo pune os vícios - como no caso da prostituta Henriette, que é condenada à morte na guilhotina por assassinar o homem que comprou sua virgindade. Convencido de que as motivações do crime livrariam Henriette do Inferno, o narrador paga ao carrasco para que lhe conceda o corpo após o suplício, decidido a dar-lhe uma sepultura decente. Consegue uma cova em um cemitério de segunda categoria, que aceitaria enterrar uma criminosa.

A cena merece atenção. Após orientar o coveiro (um tipo um tanto desonesto) a aprofundar a fossa (que desconfiou que estivesse muito rasa), o narrador vê chegarem os guardas que lhe entregariam os pedaços do corpo. Um deles abre um embrulho, do qual rola uma cabeça coberta de sangue, os belos cabelos de Henriette arrancados pelo fio da lâmina, seus olhos apagados ainda abertos, a boca horrivelmente contraída, fechada de um lado e totalmente aberta do outro; o maxilar endu- 
recido, crispado, impressiona o narrador. Ainda mais abalado ele fica ao ver que o corpo dentro de um cesto ensanguentado estava inteiramente nu.

Após enterrá-la, o coveiro, bastante embriagado, se põe a dançar sobre a fossa, cantarolando "J'aime mieux boire!" O narrador se prostra de joelho e, estarrecido, começa a rezar, enquanto o velhaco continua saltitando alegremente: "J'aime mieux boire!"

A escatológica sequência não seria a derradeira. $\mathrm{Na}$ manhã seguinte, o narrador volta ao cemitério levando flores para Henriette. No local, porém, nada encontra além de um buraco vazio no chão. Estudantes de medicina roubaram o cadáver, o coveiro vendeu o caixão à família de outro condenado: “Rien n’était plus."A escabrosa história de injustiças de Jules Janin obteve grande sucesso, sendo reeditada 17 vezes no decorrer do século XIX.

Seguiu seu exemplo a coletânea Champavert, contes imoreaux, de Petrus Borel, de 1833, um desses livros que reverberaram na sensibilidade romântica com suas incontáveis crueldades. As atrocidades macabras se repetem por todas as novelas compiladas, chegando a excessos refinados, como na história do anatomista que envenena os amantes da mulher e realiza autópsias com eles ainda vivos (e guarda os corpos em seu laboratório), ou do poeta que, antes de cometer suicídio, deseja rever o cadáver do filho morto ainda bebê. Com suas próprias mãos, desenterra o esqueletozinho coberto de carnes pútridas. Ateu, o cadáver decomposto da criança é, para ele, a prova derradeira de suas convicções.

Ao lado dessas imagens do macabro asqueroso, a sensibilidade romântica forjou o que parece ser seu extremo oposto. Do Melmoth, the wanderer (1820), de Charles Maturin, por exemplo, provém a idéia de uma "beleza cadavérica", essencial para uma certa fruição do cadáver, aquela que, mais do que explorar seu aspecto terrorífico, celebra sua dimensão estética.

O livro todo é um compêndio de improbidades difíceis de contabilizar. Melmoth aparece nos momentos de extrema dificuldade nas vidas de uma série de personagens, na tentativa de partilhar com eles o pacto que fez com Satanás. Interessa aqui, particularmente, um trecho no capítulo 28, no qual a família de Guzman, após sua morte, padece da mais terrível penúria.
Desesperados pela fome, cada um tenta, à sua maneira, ajudar: os mais velhos, junto ao caçula Maurice, recorrem à mendicância, a bela Julia se prostitui, o varão Everhard vende seu próprio sangue.

Uma noite, Ines, a mãe, ouve gemidos que vêm do quarto dos filhos. Já não se assusta mais, acostumou-se, pesarosa, com os lamentos surdos dos jovens que dormem famintos. Ao seu lado, o marido Walberg dormia profundamente. As lamúrias cessam mas, em seguida, Maurice aparece ofegante diante de sua cama, completamente lavado em sangue, chorando: "- It's Everhard's blood - he is bleeding to death, - I am covered with his blood! - Mother - mother - rise and save Everhard's life!"

Absorta por alguns instantes pela visão do caçula ensanguentado, Ines parece entrar em uma espécie de pesadelo, sensação intensificada pela fraqueza da desnutrição. A voz de Maurice a traz de volta à realidade $\mathrm{e}$ eles correm em direção ao quarto. Ao entrar, a mãe se depara com o mais velho estendido na cama encharcada pelo líquido vermelho, que lhe escorria por todo o corpo, pois os braços, de cujas veias jorrava o fluido, estavam jogados sobre a cabeça: "His arms were tossed above his head, and the blood was trickling fast from the opened veins of both, - his bright and curled hair was clotted with the red stream that flowed from his arms, - his lips were blue, and a faint and fainter moan issued from them as his mother hung over him." A luz da lua, que entrava abundante pelas janelas abertas do quarto quase sem mobília, refletida no corpo pálido e agonizante, compunha uma imagem "worthy the pencil of a Murillo, a Rosa, or any of those painters, who, inspired by the genius of suffering, delight in representing the most exquisite of humens forms in the extremity of human agony." O jovem era, nesse momento, a representação de "a kind of corpse-like beauty", um tipo de "beleza cadavérica", que os mortos, imóveis e lívidos, possuem, comparável à das estátuas de mármore: "The snow-white limbs of Everhard were extended as if for the inspection of a sculptor, and moveless, as if they were indeed what they resembled, in hue and simmetry, those of a marble statue."

A partir desse trecho, exemplar da adoração romântica pelos mortos, cabem algumas considerações. Se o macabro romântico foi devedor, em certo sentido, do macabro medieval, é certo que ele desenvolveu-se 
também a partir de princípios próprios. Mais do que enfatizar a passagem do tempo e a vanidade do mundo material, ele propunha o louvor de coisas desprezíveis e repugnantes como a putrescência. Tal premissa estética, a sensibilidade romântica herdara de um paradigma que desde o século anterior invadia os debates sobre a filosofia da arte e as teorias de recepção: o conceito de sublime.

\section{O sublime e o macabro}

A problemática do despertar da consciência estimulada pela experiência da sublimidade remete a, pelo menos, Edmund Burke, em Uma investigação filosófica sobre a origem de nossas idéias do sublime e do belo, de 1757, texto que busca caracterizar os tipos de objetos sublimes e repercute amplamente à época, influenciando pensadores do quilate de Immanuel Kant. O filósofo alemão dilapida o conceito na Crítica da Faculdade de Juízo, de 1790; nele, a sublimidade se torna subjetiva, resultante de um juízo estético, e não mais objetiva, como em seu predecessor. Mas é com Friedrich Schiller, em dois ensaios publicados entre 1793 e 1795 (Do sublime e Sobre o sublime, respectivamente), que a noção retorna ao objeto artístico, e recebe a forma pela qual seria adotada no Romantismo.

Em resumo, a experiência do sublime, tal como já aparecia em Burke, proviria do contato com um objeto sublime - "tudo que seja de algum modo capaz de incitar ideias de dor e de perigo, isto é, tudo o que seja de alguma maneira terrível ou relacionado ao terror" (1993, p. 48). Para Kant, esse objeto seria necessariamente um elemento ou fenômeno da natureza grandioso e atemorizante (o oceano, o céu, uma cadeia de montanhas, um abismo, uma tempestade, etc.), diante do qual o homem, em sua sensibilidade física, se sente inferior, mas, ao mesmo tempo, se esforça em superá-lo por meio de suas ideias, transcendendo sua condição humana. Dentro da educação estética do indivíduo romântico, alcançar a experiência do sublime seria altamente desejável, pois, colocando em conflito a sensibilidade e a razão, ele exercitaria sua humanidade. Ou seja, muito além do simples desejo de épater le bourgeois, o Romantismo buscou a experiência do sublime para seu próprio aprimoramento filosófico.
A novidade inserida por Schiller no debate moderno (retomando, de certa maneira, Burke) é o entendimento de que o objeto sublime não precisa ser necessariamente um elemento ou fenômeno real da natureza - tal como alegava a crítica kantiana-, podendo ser também, sua representação. ${ }^{7}$ Sem precisar subjugar o corpo e sofrer violência, ainda seria possível vivenciar o objeto por meio da arte. Porque imita a aparência, mas não a realidade, essa imagem coloca o homem frente ao sublime, mesmo que de segunda mão, fornecendo igualmente uma experiência legítima.

Quando o cadáver decomposto aparece na literatura, ele representa a morte em toda sua platitude, isto é, como total dissolução do corpo, como um fim, e não como esperança de salvação. Essa morte absoluta, intangível, é grandiosa por sua inexplicabilidade. A vida que acaba, misteriosamente, tal como inicia, é um evento sublime, temível. $\mathrm{O}$ último suspiro talvez seja o ato humano mais assombroso de todos. E, contudo, nada é mais fascinante do que o segredo da existência. Nada há que seja tão repulsivo e tão atraente ao mesmo tempo. Essa mistura de sentimentos é própria da experiência sublime e provoca deleite, ou, um horror deleitoso, segundo Burke. Ainda de acordo com o autor inglês, nesse sentido, a morte, ou a ideia da morte, é a maior fonte desse sentimento, uma vez que é causa da paixão mais profunda e intensa, aquela ligada à autopreservação. E ela não seria despertada apenas pela imagem do morto, mas por tudo que potencialmente possa gerar o medo da morte, presente nas figuras da falta absoluta (o vazio, a escuridão, o silêncio, a solidão) ou da vastidão inatingível (o oceano, o céu, um abismo, a natureza exuberante e ameaçadora).

$\mathrm{Na}$ solidão de um mundo racional que atomiza o sujeito, diante de todas as coisas e dos outros, essa é a resposta ao desejo de reintegração ao conjunto, ao universal. A experiência sublime do macabro contorna o caráter trágico da existência, fazendo da morte fonte de prazer e admiração, proporcionando a elevação espiritual diante da imagem da dissolvição orgânica. Daí a retomada do imaginário macabro ir além da mera voga medievalista, adequando-se aos princípios ideológicos do Romantismo. 


\section{Notas}

1. Em 1785, todo o cemitério foi removido em um processo de retirada dos cemitérios do centro de Paris. As ossadas foram transferidas para as catacumbas sob a catedral de Notre-Dame. No local, manteve-se apenas uma fonte, que data de 1549, no centro do quarteirão, que se transformou em local de feira. Em 1856, a quadra se tornou praça (Place Joachim du Bellay).

2. As referências, aqui, são as listas de Utzinger (1996), de Infantes (1998) e de Corvisier (1998).

3. Retirado de CHAMPION, 1923, p. 129.

4. VILlON, François. Oeuvres complètes. Paris: Picard, 1867, p. 227.

5. É Michel Vovelle quem nos fornece o dado. O historiador fez um longo e aprofundado estudo sobre as transformações dos testamentos, que aparece em Piété baroque et déchristianisation en Provence au XVIIIe siècle. Les attitudes devant la mort d’après les clauses des testaments. Paris: Plon, 1973.

6. A poésie des cimetières, por sua vez, além da influência gótica, teria parentesco com os Graveyard Poets ingleses, cujos principais representantes seriam Edward Young (The Complaint, or Night Thoughts on Life, Death and Immortality, de 1742) e Thomas Gray com sua Elegy written in a country churchyard, de 1751. Entre 1761 e 1830, o poema de Gray teve nada menos que 90 traduções para o francês. Na Alemanha, eles inspirariam o surgimento dos "poetas da noite", os Nachtgedankenmächer. (VOVELLE, 1983, p. 472 e 477). Todos produziam, em geral, reflexões sobre a morte. Nos interessa, contudo, enfatizar, nesse momento, as produções posteriores a eles, que fizeram uso do elemento macabro mais explicitamente.

7. Daí o interesse notável dos artistas do início do século XIX pela pintura de paisagem, em detrimento de outros temas. Como caminho para o sublime, essas obras visavam aos mesmos efeitos grandiosos e simbólicos da natureza, expressando sentimentos e estimulando ideias. Não por acaso, o termo romântico era aplicado à essa pintura paisagística.

\section{Referências}

ARIĖS, Philippe. O homem diante da morte. Volume I. Rio de Janeiro: Francisco Alves Ed., 1989.

História da morte no Ocidente. Rio de Janeiro: Ediouro, 2003.

BÉGUIN, Albert. Lâme romantique et le rêve. Essai sur le romantisme allemand et la poésie française. Paris: José Corti, 1986.

BOREL, Pétrus. Champavert: contes immoreaux. Paris: Eugène Renduel Éditeur-Libraire, 1833.
BURKE, Edmund. Uma investigação filosófica sobre a origem de nossas idéias do sublime e do belo. Campinas: Papirus, Editora da Universidade de Campinas, 1993.

CHAMPION, Pierre. Histoire poétique su quinzième siécle. Tomes I et II. Paris: Honoré Champion Editeur, 1923.

CORVISIER, André. Les danses macabres. Collection Que sais-je?. Paris: Presses Universitaires de France, 1998.

GAUTIER, Théophile. Mademoiselle de Maupin. Nouvelle Édition. Paris: Charpentier et Cie, 1876.

GOMES, Álvaro Cardoso e VECHI, Carlos Alberto. A estética romântica. Textos doutrinários comentados. São Paulo: Atlas, 1992.

GUINSBURG, Jacó (org). O Romantismo. São Paulo: Perspectiva, 1993.

HOBSBAWM, Eric. A era das revoluções. Europa 17891848. Rio de Janeiro: Paz e Terra, 2006.

HUIZINGA, Johan. O outono da Idade Média. Estudo sobre as formas de vida e de pensamento dos séculos XIV e XV na França e nos Países Baixos. São Paulo: Cosac Naify, 2010.

INFANTES, Víctor. Las danzas de la muerte. Génesis y desarrollo de un género medieval (siglos XIII-XVII). Salamanca: Ediciones Universidad de Salamanca, 1997.

JANIN, Jules. Lâne mort et la femme guillotinée. Paris: Adolphe Delahays Éditeur, 1861.

KANT, Immanuel. Crítica da Faculdade do Juízo. Tradução de Valério Rohden e António Marques. 3a edição. Rio de Janeiro: Forense Universitária, 2012.

LEWIS, Mathew Gregory. The monk. E-book disponível em http://www.gutenberg.org/files/601/601-h/601-h. htm Postado pelo Project Gutenberg, em 2008.

MATURIN, Charles Robert. Melmoth, the wanderer. E-book disponível em http://ebooks.adelaide.edu. $\mathrm{au} / \mathrm{m} / \mathrm{maturin} / \mathrm{charles} / \mathrm{melmoth}$ the_wanderer/ index.html Postado pela University of Adelaide Library, em 2005.

MORAES, Eliane Robert. Sade: a felicidade libertina. Rio de Janeiro: Imago, 1994.

MORIN, Edgar. O homem e a morte. Rio de Janeiro: Imago, 1997.

NODIER, Charles. Critique littéraire. Le petit Pierre, traduit d'allemand, de Spiess. In: Annales de la littérature et des arts. Tomo II. Paris, 1821. Disponível em <https://archive.org/details/annalesdelalitt02soci $>$

PAZ, Octavio. Os filhos do barro. Do Romantismo à vanguarda. Rio de Janeiro: Nova Fronteira, 1984. 
SCHILLER, Friedrich. Do sublime ao trágico. Organização de Pedro Sussekind. Belo Horizonte: Autêntica, 2011.

UTZINGER, Hélène et Bertrand. Itinéraires des Danses macabres. Chartres: Éditions J.M. Garnier, 1996.

VAILLANT, Alain (dir). Dictionnaire du Romantisme. Paris: CNRS Editions, 2012.

VILLON, François. Oeuvres complètes. Paris: Picard, 1867.

VOVELLE, Michel. La Mort et l'Occident de 1300 à nos jours. Paris: Gallimard, 1983.

Recebido em: 02/06/2015

Aceito em: 14/09/2015 
